\title{
DOI: 10.7596/taksad.v10i1.3009
}

Citation: Bekcan, U., \& Uz Hançarlı, P. (2021). Evaluation of Eurovision Song Contest as a Cultural Impact Tool. Journal of History Culture and Art Research, 10(1), 84-97. doi: http://dx.doi.org/10.7596/taksad.v10i1.3009

\section{Evaluation of Eurovision Song Contest as a Cultural Impact Tool}

\author{
Umut Bekcan¹, Pınar Uz Hançarlı²
}

\begin{abstract}
In this study, three claims/arguments regarding the emergence and function of the Eurovision Song Contest were put forward and tried to be grounded. First, the contest emerged as a tool for Western Europe to influence Eastern Europe culturally in the Cold War but it didn't become an ideological conflict area of East-West. Second, the contest functioned as a stage of expressing the political problems/situations that countries experience within themselves or with each other in the Cold War era and aftermath. Third, although Turkey took place in the Western Europe side in the Cold War, this contest made Turkey feel non-European while having a different identity. In this context, the subject is discussed from the historical perspective with the assumption that the subject of history is unique. The study focused primarily on the concept of the Cold War and the contest. Then, it was explained with the examples which political problems/situations different from the Cold War ideological conflict environment were brought up on the contest platform. Finally, it was emphasized that the contest contributed to "us vs them" dichotomy in Turkey against Europe, contrary to Eurovision's aim to form/create a common European culture.
\end{abstract}

Keywords: Cold War, Eurovision Song Contest, Turkey, Politics, Music.

\footnotetext{
${ }^{1}$ Assoc. Prof. Dr.. Pamukkale University, FEAS, Department of Political Science and Public Administration, Denizli, Turkey, E-mail: ubekcan@pau.edu.tr

${ }^{2}$ Research Assistant Dr. Pamukkale University, FEAS, Department of Political Science and Public Administration, Denizli, Turkey, E-mail: puz@pau.edu.tr
} 


\section{Kültürel Bir Etki Aracı Olarak Eurovision Şarkı Yarışması Üzerine Bir Değerlendirme}

\section{Öz}

Bu çalışmada, Eurovision Şarkı Yarışması'nın ortaya çıkışı ve işleviyle ilgili üç iddia/argüman ortaya kondu ve temellendirilmeye çalışıldı. Bu iddialardan birincisi, Eurovision Şarkı Yarışması'nın Soğuk Savaş döneminde Batı Avrupa'nın Doğu Avrupa'yı kültürel etkileme aracı olarak ortaya çıktığı ama doğu-batı arasında ideolojik çatışma zemini oluşturmadığıdır. ikincisi, yarışmanın Soğuk Savaş döneminde ve sonrasında, ülkelerin kendi içinde ya da birbirleriyle yaşadıkları siyasi sorunların/durumların ifade edildiği bir sahne işlevi gördüğüdür. Üçüncüsü, Türkiye Soğuk Savaş’ta Batı Avrupa tarafında yer almasına rağmen bu yarışmanın Türkiye'ye Avrupalı olmadığını, farklı bir kimliğe sahip olduğunu hissettirmesidir. Bu bağlamda, konu tarihsel perspektiften ve tarihin konusunun biricik olduğu bilinciyle ele alındı. Çalışmada öncelikle Soğuk Savaş kavramı ve Eurovision Şarkı Yarışması üzerinde duruldu. Ardından, Soğuk Savaş’ın ideolojik çatışma ortamından farkıı olarak ne gibi siyasi sorunların/durumların yarışma platformunda gündeme getirildiği örneklerle açıklandı. Son olarak, Eurovision'un ortak Avrupa kültürü oluşturma amacına aykırı bir şekilde Türkiye'de Avrupa'ya karşı, "biz ve onlar" ayrımının yapılmasına katkı sağladığı vurgulandı.

Anahtar Kelimeler: Soğuk Savaş, Eurovision Şarkı Yarışması, Türkiye, Politika, Müzik.

\section{Introduction}

Eurovision Song Contest (ESC) is a musical-entertainment organisation and composition competition which has become a tradition, so to say, coming to this day from the 1950 s and turning into a visual show by being depended on the circumstances and technology of the time. The organisation began in warworn Europe on the bitter days of the Cold War. It has sparked a considerable interest also in Turkey since the first broadcast of Turkish Radio and Television Corporation (TRT). The contest was seen as equally important as a national team game or a game of one of the Turkish football teams playing in the European arena in the 1970s and 1980s and watched with enthusiasm and keen interest by being considered as a kind of "national matter".

In this study, three arguments related to the emergence and functions of ESC will be explored. First of all, although ESC was born in the Cold War era as a mechanism of Western Europe to influence the East culturally, it did not create an ideological conflict between the East and West. Secondly, the contest has become a stage in the Cold War days and afterwards where the intra/interstate political problems were reflected. Finally, although Turkey was a part of Western Europe in terms of Cold War polarization, this contest made Turkey feel as non-European with a different identity.

In this context, the topic was covered with a historical perspective and awareness of the fact that the subject of history is unique. The study will be divided into three parts. In the first one, the concepts of the Cold War and ESC will be elaborated. Then, what kind of political problems/situations will be carried to the contest platform, other than the results of the Cold War's ideological conflict environment, will be discussed with examples. Finally, the contest will be examined from the perspective of Turkey and how Turkey considered ESC will be analysed. It will be emphasized that contrary to ESC's aim to create a European culture, in Turkey, the contest has contributed to "us vs them" dichotomy on the issue of Europe. 


\section{Eurovision Song Contest as an instrument of Cold War}

In 2011, a documentary titled The Secret History of Eurovision was broadcasted on different channels in the world. This Australian production documentary directed by Stephen Oliver and distributed by BBC Worldwide was claiming that ESC was an instrument of Western Europe to influence the East culturally in the Cold War days (Oliver, 2011). After the Second World War, the alliance between the USA, the United Kingdom and France on the one hand and the USSR on the other were collapsed and contestation of influence over the capitalism-socialism dichotomy called Cold War emerged. One of the events that could lead to the beginning of the Cold War was the Long Telegram of the ambassador of the USA to Moscow dated 22 February 1946 which mentioned a Soviet threat and the need for its containment and following this, the British Prime Minister of the time, Winston Churchill's speech on 5th of March in Missouri-Fulton, USA arguing that "From Stettin in the Baltic to Trieste in the Adriatic, an iron curtain has descended across the Continent". The second event paving the ground for Cold War was the president of USA of the time, Harry Truman's declaration of his infamous doctrine embracing military aid to Greece that was then in the middle of a civil war between right-left wing groups and Turkey perceiving threat from the USSR. Thirdly, the implementation of Marshall Plan by the USA in 1948 aiming to develop Europe via a capitalist economy could be considered as one of the events leading to the emergence of the Cold War. At the end of the day, the foundation of NATO (North Atlantic Treaty Organisation) by Western Europe's capitalist countries with the leadership of the USA consolidated the above-mentioned events (Tellal, 2013: 74). The main problem for the USA and Western Europe was the threat of communism as socialist parties were coming to power in Eastern Europe (Bulgaria, Romania, Poland, Czechoslovakia, Hungary, East Germany, Yugoslavia, Albania) in the meantime. The prestige of USSR had increased not only in the East but also in Western Europe after its significant contribution to the defeat of Nazi Germany. Political parties embracing communism gained many members and shared power with other parties also in the West. The high level of unemployment and inflation and the collapse of the European economy also affected the circumstances. The USA and Western European states were considering throwing off the Soviet impact in Europe. The Cold War was a struggle not just in the political, military and economic realm but also at the socio-cultural level. Within this context, the Central Intelligence Agency (CIA) put an important effort and created a budget to get an edge over the USSR and Eastern bloc at the cultural level. Anti-communist literature and art were promoted in this cultural propaganda war. The aim was to bring the perspective of USA for the intellectuals and nations in Western Europe sympathizing with communism (Saunders, 2016).

In this environment, the procedure of making ESC an instrument of the Cold War started in 1946 when 28 European and African national radio channels came together and established International Radio Organisation (IRO). According to the USA, the USSR and Eastern European countries were trying to make an impact on the non-communist majority within the organisation. Therefore in November 1949, Algeria (under French control), Belgium, France, Italy, Luxemburg, Morocco (under Spanish and French control), Tunisia (under French control) and Vatican left IRO leading to weakening of the organisation which was a democratic combination of different ideologies. CIA subsidized television infrastructure in Europe and thus on February 12, 1950, British Broadcasting Corporation (BBC) founded a non-communist organisation named as European Broadcasting Union (EBU), which was rival to IRO, in Geneva/Switzerland (United States Congress, 1978: 618). After the Second World War, the aim of the capitalist bloc was to establish closer relationships among Western European countries with the help of culture sharing and contact and, as a result, to form a common European identity. Close relations were hoped to boost the economic welfare and ease the struggle against "the ghost of socialism and USSR" (Hintermayr, 2016). Reconciliation of West Germany with Western Europe was 
also essential after the war (Wellings and Kalman, 2019: 1-2). ${ }^{3}$ It was emphasized that the war was over and the war days had to be forgotten. In the bitter Cold War days, historical Franco-German enmity ${ }^{4}$ had to be ended. Because there was a serious threat, which was from the USSR, to European society and culture. In this context, EBU organised the first ESC in $1956 .{ }^{5}$ The contest was considered, on the one hand, as an opportunity to examine how far the broadcast network of EBU could reach and as a kind of celebration for the success of the European unity and capitalism, on the other. It was part of European cultural integration. Donald Sassoon, a professor of European history, was summarizing the message envisaged by ESC as "here, there is fun and freedom and there, there is the boring communism" in the documentary titled "The Secret History of Eurovision" (Oliver, 2011). The contest had a function of indicating the things were going well in the West and making the East jealous and this was achieved. As a result, Eastern bloc organised its own contest within the understanding of the Cold War's "we can do the better". Countries from Africa, Asia, Central and Southern America were represented by their songs in the contest held each year. ${ }^{6}$

According to the above-mentioned documentary, the USSR was trying to block the broadcasts. However, the contest was being watched in Eastern Europe, especially in Eastern Germany (Oliver, 2011). It can be argued that this claim is disputable or inconvenient for generalization. Because according to Vuletic (2017), socialist countries in Eastern Europe censored Western popular music not only because it was "Western". Both in ESC and Intervision, the songs competing were in the same popular genre and similar versions of ESC were held in Eastern Europe. Socialist alternatives were produced in Eastern Europe as in the fashion of Western Europe. In other words, there was an obvious cultural interaction between the West and East. The Czech singer Karel Gott's case was an important example to indicate that it was an independent contribution from the ideology to European culture. He represented Austria in ESC of 1968. He was very famous in German-speaking geography and in both sides of the "Iron Curtain". He was symbolizing a common cultural heritage. In the same year, he had participated in Intervision on behalf of Czechoslovakia and was ranked as the first (Vuletic, 2017). Again in the same year, in Czechoslovakia, a democratisation process named as "Prag Spring" began. At this point, it is hard to say something on the choice for Gott whether it was a conscious political move or

\footnotetext{
${ }^{3}$ In the first contest, West Germany was represented by a Jewish singer, Walter Andreas Schwarz, as a compromise of Jewish genocide legacy. (Watson \& Slee, 2019)

${ }^{4}$ Franco-German enmity had been a constant element of European history from the time of German unification in 1871 to the beginning of First World War in 1914. This enmity endured even until the end of Second World War (Sander, 2003: 247-248).

${ }^{5}$ In 1951, West Germany, France, Italy, Belgium, The Netherlands and Luxemburg founded European Coal and Steel Community (ECSC). In those days, ECSC became a success and a more extensive one, European Economic Community, was on the way. The first contest was held in Lugano/Switzerland in 1956, inspired from Sanremo Music Festival. ECSC countries and Switzerland were the participants of the first event. ("The first ever contest", 2021)

${ }^{6}$ The contest is known as Sopot (Intervision) International Song Contest. The first event was held in 1961, in Gdansk/Poland and later on in a tourism city, Sopot. The founding father of the contest was a pianist from Poland, Wladyslaw Szpilman. He was a Jewish musician working for Polish radio before the Second World War. On September 23, 1939, he was playing live Chopin's Nocturne No.20 C-sharp Minor while the Nazis were bombing Warsaw from the ground and air. That was the last live music played from Polish radio until the end of war. The contest was open to all artists coming from different parts of the world and it was aiming to surpass ESC and introduce itself as one of the leading music festivals. Cuba participated regularly. Finland that had guaranteed not to be involved in any political/military alliance to the USSR in 1948 and Yugoslavia that was distant to the USSR participated in both ESC and Sopot. Some singers from Western bloc, such as Gloria Gaynor, Petula Clarke and Boney-M, took the stage in Sopot as special guests (Rosenberg, 2012). On the other hand, historian Dean Vuletic (2017) argued on the basis of archive documents of Czechoslovak and Polish televisions that Intervision was a contest led not by USSR but Czechoslovakia and Poland.
} 
not but it is a fact that Austria was a permanently neutral state in terms of international law. This choice was indicating that Austrian state television was acting as a bridge between EBU and OIRT ${ }^{7}$ (Vuletic, 2017).

Today, although it is mentioned in the official website of ESC that all the necessary measurements shall be taken by the host and participant broadcasting institutions to prevent the politicization of the contest or to avoid contest's being an instrument of any policy ("Rules", 2021), the contest has sometimes been an issue of politics since its beginning. However, the contest's commitment to Cold War's ideological confrontation remained limited and it was mostly restricted to the founding aim. In other words, ESC was not a platform in the Cold War era where capitalist states criticized or discredited the socialist ones implicitly or explicitly.

\section{Eurovision Song Contest as a matter of (international) politics}

The contest had a liberal perspective. Europe had struggled against fascism recently. Spain and Portugal were also under fascist regimes. However, this did not prevent Spain and Portugal, since 1961 and 1964 respectively, from participating in the contest. Even Yugoslavia having a distant relationship with the USSR prefered to take part in ESC (Hintermayr, 2016). These cases were consolidating ESC's political stance. It was not humiliating the socialist Eastern bloc for any reason. Mostly because, socialist Yugoslavia was one of the participants, the organisation did not want to offend the peoples of the Eastern bloc that were following the event closely and there was an attempt to avoid a political crisis between the blocs of West and East. However, during the Cold War and also afterwards, the contest has sometimes been a matter of politics, -even the international politics as the Arap-Israel conflict became an issue - as a stage where the political problems within or among capitalist states came into question.

One of the example cases was related to Spanish domestic politics. In 1968, Spain under Franco's fascist regime would be represented by Joan Manuel Serrat from Catalonia. Since he wanted to sing in the Catalan language, he was not allowed to participate in the contest held in London. Instead, Massiel born in Madrid took part in the contest with her song titled La La La and lead it by 1 point ahead of Cliff Richard representing the United Kingdom who sang the song Congratulations. ${ }^{8}$

Although there were members of EBU from North Africa and Arab countries, they, except Morocco, did not participate in the contest as they were against Israel's membership (Riegert, 2019). ${ }^{9}$ As a result, Arab-Israel conflict was felt also in the stage of ESC. Moreover, after a militant Palestinian group took hostage 11 Israeli athletes in 1972 Munich Olympic games and following the operation of German police some Palestinians and athletes were dead in an incident called Munich Massacre, 1973 ESC held in Luxemburg became a stage of the reflection of the events. The representative of Israel sang by wearing a bullet-proof vest (Levy, 2009). In the year 1991, when the Palestinian state founded in 1988 and Israel came together officially for the first time in Madrid Conference, the latter attended ESC with a song of peace and friendship with Palestinian people and took third place (Kuyucu, 2011: 215). In 2000, the group, Pingpong, representing Israel waved the flag of Syria in the rehearsals by leading to a crisis. Israel National TV channel (IBA)'s attempt to withdraw the group from the contest

\footnotetext{
7 IRO was renamed as International Radio and Television Organisation (OIRT) in July, 1959 (United States Congress, 1978: 618)

8 In that year's contest, there were rumours that Spain's leader Franco gave promises to the executives of the other national TV channels to buy series and programs and in return, he demanded the votes and made Spain rank as the first (Levy, 2009).

${ }^{9}$ Morocco only attended once in 1980 and gave 12 points to Turkey represented by Ajda Pekkan with her song titled Petrol ("The Hague 1980, 2021).
} 
became an issue. Members of Pingpong declared their will to live together peacefully with Arab countries and emphasized that their song was about love and peace. At the end, the group took part in ESC with their song titled Sameach yet the head of IBA argued that they were not representing Israel, but only themselves and they would meet their own expenses (Goldenberg, 2000).

ESC was a "mean" for the beginning of Carnation Revolution and the democratization process in Portugal under fascist regime like Spain. On the contest held on April 6, 1974 Portugal's representative Paulo de Carvalho's song E depoi do adeus (and after the goodbye) became the slogan of the military coup and on April 25, 1974 after it was played in Portugese radio, Carnation Revolution began and dictatorship was abolished (Levy, 2009). In the same year's contest, Italy took part with Gigliola Cinquetti's song Si (Yes) but the song was not broadcasted in Italian television. On May 12, 1971 there would be a referendum in Italy for the continuity of a law enacted in 1971 which was legalizing the divorce. The lyrics of the song was not related to the referendum question but there were many "yes" word and this bothered Italian television RAl. It banned its own song until the end of the referendum (Wolther, 2012: 168).

In 1975, Turkey participated in ESC for the first time. In the national selection, although Ali Riza Binboğa's song titled Yarınlar Bizim (Tomorrow is Ours) got the vast majority of the votes out of the public voting, it was not selected due to jury's low points. The reason was considered as left-wing substance in the lyrics (Kuyucu, 2011: 41). Morever, ESC of 1975 was the one that Greece did not take part in due to its protest of Turkish military intervention in August, 1974. In the contest of 1976, TRT did not broadcast the song of Greece (Watson \& Slee, 2019). Greece was being represented by Mariza Koch's song titled Panaghia Mou, Panaghia Mou (My Lady, My Lady). The song was protesting implicitly the Turkish presence in Cyprus (Levy, 2009; Jordan, 2010). The contest was held in Israel, in 1979. Turkey renounced its participation due to Arab countries' reaction to the peace agreement signed by Egypt and Israel a few days before the contest and Israel's choice of Jerusalem as the host city of the event. Even, Turkey accepted to pay the related fine (Kuyucu, 2011: 65). The oil crisis of the time affected Turkey negatively and it was trying to have good relationships with Arab countries due to its need for oil.

Cyprus joined the contest in 1981 for the first time. TRT did not broadcast the songs of Cyprus in 1981 and 1982 (Kuyucu, 2001: 99, 110). In 2003, when Annan Plan aiming to unite the island was on the table for the negotiations on Cyprus problem, Cyprus gave 8 points to Turkey contributing to latter's ranking first in the contest. ${ }^{10}$ The next year, Cyprus gave 4 points to Turkey (Kuyucu, 2011: 287).

In 1981, Luxemburg was represented by French Jan-Claude Pascal's song titled C'est Peut-etre Pas L'Amerique (It may not be America). The song was praising Europe and its lifestyle by saying that the winds of Southern France and the music heard there were prefered instead of the American genre. This song was considered as a criticism against the neo-conservative president of USA, Ronald Reagan who came to power in the same year. The contest of 1982 was held in the United Kingdom when the Falkland War between the United Kingdom and Argentina was going on. Spain's participation in the contest with a tango music renowned in Argentina, a former colony of Spain, was perceived as a protest against the United Kingdom (Levy, 2009).

In the contest of 1988, Turkey gave its first points (3 points) to Greece (Kuyucu, 2011). In the same year, Turkey and Greece represented by their prime ministers Turgut Özal and Andreas

\footnotetext{
${ }^{10}$ The host announced the points given by Turkey as "Europe! Peace to Cyprus, Turkey eight points" (Jordan, 2011: 48)
} 
Papandreou had taken a step forward for good relations in the summit held in Davos/Switzerland. Turkey was in need of this move to be accepted in the European Community (European Union since 1992) after its full membership application in 1987.

The fall of Berlin Wall in November 1989 was a symbol for the end of the Cold War. The new political environment could be seen in the contest of 1990. The collapse of the Wall was welcomed in the context of unity and freedom in Europe. Italy won the contest with its song titled Insieme 1992 (Together 1992) with its lyrics of the dream for a united Europe. In the same year, West Germany's Frei Zu Leben (To Live Freely), Austria's Keine Mauern Mehr (No Walls Anymore), Norway's Brandenburg songs greeted the new era (Oliver, 2011).

With the end of Cold War, socialism also fell in Eastern Europe in the 1990s. In this period, when the bloody dissolution of Yugoslavia and the wars in Bosnia and Kosova were witnessed, the phenomenon of identity/nationalism rised all around the world but especially in Eastern Europe. The contest was considered as an instrument constituting or strengthening the national identity. Moreover, ESC was signifying common European identity, regime change and "freedom", a trending concept of the time, for Balkans and Eastern European countries after the Cold War. They were eager to be involved in this superstructure organisation in the period of transition to the capitalist economy. Even in 1993, Bosnian contestants took part in ESC and left their country by risking their lives amid the war. They found a chance to express their wish to live in peace with the anti-war theme in their song. After NATO's military intervention to Serbia in 1999, in ESC held in Jerusalem, the participants sang the Israel's winner song/hymn of 1979, Hallelujah, together at the end of the event by dedicating it to the victims of war (Oliver, 2011). Europe was confessing its sins, so to say, with this song, as it was unable to prevent or stop the war on the dissolution of Yugoslavia, in the middle of its borders in addition to its acceptance or obligation to accept NATO intervention.

In 2002, the contest was held in Estonia that had won ESC of 2001. It was a significant event for the country as it was in a period of identity construction in the post-Soviet era. Siim Kallas, the prime minister of Estonia, was emphasizing the symbolic importance of ESC hosted by his country as it was the year that Estonia would conclude the negotiations on the membership with European Union (EU). All the efforts and aspirations of the Estonian people were believed to result as a success (Wolther, 2012: 168-169). In 2005, Ukraine took part in ESC with a song titled Razom Nas Bahato (Together We Are Many) which was a support for pro-Western Viktor Yushchenko coming to power in 2004 after "Orange Revolution". After a warning from EBU, the part in the lyrics containing Yushchenko's name was taken off (Kuyucu, 2001: 337). ESC was a bridge, so to say, connecting Estonia and Ukraine to Western Europe. ${ }^{11}$

In March 2006, in the national selection day of the Serbia-Montenegro jury of Montenegro did not vote for Serbian singers in the national selection and a contestant from Montenegro ranked as first. This resulted in a major reaction in the event hall. Serbian television did not accept the result. Newspapers from Montenegro claimed that the federal state was not functioning not only on a political and economic level but also musically. Serbia-Montenegro did not take part in the event in May and dissolved into two different countries in June (Serbia-Montenegro in pop song row, 2006).

Turkey gave 10 points to Armenia in 2006, 12 points in 2007 and 10 points in 2008. This was not welcomed by the Great National Assembly of Turkey and led to disputes. TRT was forced to announce

\footnotetext{
${ }^{11}$ For a detailed analysis of ESC's contribution to nation building process and the cases of Estonia and Ukraine as examples see also Jordan, P. (2011). The Eurovision Song Contest: Nation branding and nation building in Estonia and Ukraine, unpublished PhD thesis Glasgow: University of Glasgow, Central \& East European Studies.
} 
televoting results. In 2009, System of a Down, a group representing Armenia wanted to join ESC with a song on 1915 events (Kuyucu, 2011: 431, 451). This was not seen as a good idea because in 2008 Turkish and Armenian presidents had watched the national football game of two countries together and started a normalisation process. In 2015, on the other hand, Armenia attended the contest with a song titled Face The Shadow by Genealogy bringing their genocide claim to the agenda and the lyrics were repeating the expression of "don't deny" frequently (Harris, 2019).

Georgia wanted to take the revenge of Russian military intervention in 2008 by joining the contest in 2009, in Russia with a song titled We Don't Wanna Put In The Negative Move. The song had also a meaning of "We do not want Putin". EBU asked Georgia to change the song but it was not accepted and Georgia withdrew from the contest. The political problems between Ukraine and Russia and the annexation of Crimea by Russia as a result of a referendum in 2014 reflected to ESC. Ukraine won the contest in 2016 with a song titled "1944" on Crimean Tatars who were exiled as they were claimed to cooperate with Nazis in the Second World War by protesting Russia. Moreover, the tension between Ukraine and Russia led to a crisis in Ukraine before the contest in 2019. National selection winner Maruv gave concerts in Russia and as a result of this, Ukraine withdrew Maruv from the contest and then renounced its participation to the event (Harris, 2019).

In 2019, for the contest to be held in Israel, there were calls for a boycott in Iceland and Ireland months before the event. The main criticisms were human rights abuses against Palestinian people by Israel and the USA's decision to move its embassy to Jerusalem in May, 2018 (izlanda ve İlanda'dan Eurovision için İsrail'i boykot çağrısı, 2018) Despite the calls for boycott, both countries joined the event in Tel Aviv. The group representing Iceland, Hatari, waved scarves having a Palestinian flag on them and due to the rules of ESC, Iceland television was fined (Iceland fined for Eurovision proPalestinian protest, 2019).

With the participation of former Yugoslavian republics and Eastern bloc countries after Cold War, the number of contestants increased. These newcomers also achieved good rankings and even got first place. This led to some criticisms in addition to the low rankings of founding countries of EBU. For example, Eurovision commentator of BBC, Terry Wogan claimed after Serbia won the contest of 2007 that the former Eastern bloc countries were united against them and were strongly backing each other. Moreover, Germany proposed a new contest only for Western European countries (Hintermayr, 2016). ${ }^{12}$

To sum up, it can be argued that all the examples given above indicate that ESC has been more than a song contest and international music feast. Although the official rules do not allow any politicization, in reality this has been the case.

\section{Perspective of Turkey towards Eurovision}

Turkey having a Western-oriented political and economic development understanding found a chance to get to know more closely and follow European music, lifestyle and popular culture thanks to ESC. As a member of NATO, it was on the side of the Western political and economic system in the Cold War days. Covered versions of famous songs in Europe were produced in Turkish and this accelerated the development of popular music in Turkey. Some ESC songs were also covered. For example, the winner of the 1968 contest, Massiel's La La La, was sung by Berkant in 1972 with the name of "ihtiyacın Olursa". Ann Marie David's song Tu Te Reconnaitras won 1973's contest and it was also sung with the name of "Göreceksin Kendini" by Nilüfer in 1975. Füsun Onal was another Turkish

\footnotetext{
12 Terry Wogan was also claiming that in 2003 the United Kingdom earned no points because the invasion of Iraq by the USA had been supported (Begley, 2013).
} 
singer singing 1975's winner song Teach-In by the group Ding A Dong with its Turkish name "Söyleyin Arkadaşlar" (Bekcan, 2012).

In addition to this, ESC put Turkey into a loser and crushed position. Definitely, this was because of its low rankings in the contest. Turkey joined ESC in 1975 for the first time and in 1978 for the second. From 1980 to 2012, it has participated each year except 1994. Until 1991, the best result of Turkey, 9th position, was the one in 1986 which was achieved by Klips ve Onlar with the song titled Halley. The reasons for failures in the contest were seen as Turkish-Muslim identity of the society, Christian Europe's exclusionist attitude and negative political stance against Turkey, instead of wrong choices of songs (Bekcan, 2012). For example, according to composer Attila Özdemiroğlu, Turkey's ranking in the last position with Semiha Yankı's "Seninle Bir Dakika" in 1975, which was the first participation to ESC, was because of Cyprus issue and Turkish military intervention in 1974 (Kuyucu, 2011: 48). Neco, who represented Turkey in 1982, reminded a question from a British journalist asking what would happen if the British navy came to Turkey in one of his interviews. This question was a reference to Falkland War between the United Kingdom and Argentina and Neco's response was "Don't you remember Çanakkale (Gallipolli)?". Similarly, Kayahan participating to ESC in 1990 expressed that one of the journalists in the contest annoyed him by saying "you have tortures" (Türkiye'nin ESC tarihi 6/4, 2012). In this way, Europe was conducting its criticisms on Turkish domestic and foreign policy to the singers. In 1983, Çetin Alp who earned no points with his song Opera claimed that if his name was Michael, the result would be different (Kuyucu, 2011: 128) and asserted that cultural differences of Turkey were a disadvantage in the contest.

Comparatively better results were used by politicians as a political leverage. Therefore, political context of the contest was accepted. The minister of Culture and Tourism of the time, Mükerrem Taş̧ıoğlu thought that 12th place in 1982 after the participation of the band, Beş Yıl Önce On yıl Sonra, with their song Halay was because of "government's favourable domestic and foreign policies". The next year, 14th place of Mazhar-Fuat-Özkan with their song Diday Diday Day did not make prime minister, Turgut Özal happy. He argued that being a Christian was needed to win the contest as no points were given to Muslims. His wife, Semra Özal was considering Seyyal Taner's earning no points as a European protest against Turkey's full membership application to the European Community (Kuyucu, 2011: 142, 152, 171). ${ }^{13}$ In 1989, Turkey was represented by Grup Pan and one of its members, Hazal Selçuk was arguing in one of the interviews that the cultural differences were very sharp and Turkey was the ugly duckling of ESC (Eurovision'a Doğru, 12. Bölüm, 2012) ${ }^{14}$ These examples were indicating that ESC has been contributing to "us vs them" dichotomy in Turkey against Europe.

From 1992 to 2003, ESC was forgotten, so to say, in Turkey. Media and public did not pay much attention. The resentment against the European Community after its rejection of Turkey's full membership application at the end of 1989 and the beginning of 1990 also contributed to this to some

\footnotetext{
${ }^{13}$ Before the contest of 1987 in Brussels, in the Queen of Belgium, Fabiola's reception Seyyal Taner had an interesting dialog with the Prime Minister of Belgium, Wilfried Marten. She said "Eurovision is ok, but when will we be joining to European Union". He looked at her and asked if she came to the contest or was sent by Ankara. Seyyal Taner responded "Yes, Ankara has sent me" (Eurovision’a Doğru, 12. Bölüm, 2012). It can be argued that this anecdote reflects Turkish political perspective on ESC.

${ }^{14}$ On the other hand, there were people arguing that low rankings in the contest were a result of Turkish pop music's falling behind of Europe. Doğan Şener from the newspaper, Milliyet, and editor in chief of Hey magazine was arguing in one of his columns after Neco won the national selection in 1982 that "we are a country in Europe that sells the least number of records. We have the least number of songwriter, composer and arranger. We do not have any vocal music except the few bands in this country. And then we ask, what will be our ranking in Eurovision..." (Kuyucu, 2011: 107, 108)
} 
extent. Moreover, it can be argued that after private television channels began to broadcast, people prefered different television programs in different channels instead of TRT and the contest that had always made them unhappy (Bekcan, 2012). The prominent singers and composers of Turkey did not show much interest in the contest. Even the 3rd place won by Şebnem Paker with her song Dinle in 1997 did not increase the enthusiasm for ESC.

From 2003 to 2012, except the year of 2005, TRT appointed -so to say-famous singers or bands to participate in the contest. In 2003, Sertab Erener's song in English, "Every Way That I Can" won the contest and this became a great source of happiness in Turkey. The government of the time tried to get a slice off the cake like the ones in 1980s. The minister of Foreign Affairs, Abdullah Gül, was thinking that the first place was achieved thanks to the prestige offered by the government. State minister, Kürşat Tüzmen was also considering that the Prime Minister Recep Tayyip Erdoğan's visits to European countries had contributed to this success of Turkey. TRT's director general of the time Yücel Yener was arguing on the other hand that the government led by Abdullah Gül had tried to avoid a song in English and the achievement could not be referred to the government (Kuyucu, 2011: 298).

In the following years, although there was not any winner from Turkey, its rankings were generally in the top ten and the public interest increased for ESC. Successful results became a matter of national pride and nationalist emotions aroused while the language of songs created confusions from the nationalist perspective. The first compromise for a song in English, despite the decision to participate with Turkish songs, was not in 2003 but in 1980. It was the song titled Pet'r Oil with its known name Petrol. In 1982, Neco's song “Peşimden Koşanlar Nerde Hani?” was aiming Europeans to perceive the word "hani" as a familiar one to "honey". In 1986, the band Klips ve Onlar was trying to get some sympathy by greeting Europeans in different languages while singing their song Halley (Bekcan, 2012). In 2000, Pınar Ayhan \& Group SOS sang Yorgunum Anla's some parts in English. Following this, in 2001 Sedat Yüce's Sevgiliye Son; in 2002 Buket Bengisu's Leylaklar Soldu Kalbinde followed the same path. After the success of 2003, Turkey participated mostly with songs in English. The aim was to reach more people and get more votes for better rankings. However, the debates on the language were on the agenda each year. ${ }^{15}$ Another issue coming to the agenda each year was the voting patterns in the contest seen as a reason of low or comparatively insufficient rankings. The concern was that there were some countries not voting for us because of "us" and the neighbours favouring each other. Bülend Özveren from TRT, who has been presenting the events and whose name always reminded people the contest, was not only explaining neighbourhood relationships and voting patterns as a result but also making some political analysis by revealing "the enemies of Turkey" (Bekcan, 2012). After all, Turkey's main reason not to attend the contest after 2012 was "the points deserved but not earned". The voting system was televoting, i.e SMS voting, between 2003 and 2009. Starting from $2009,50 \%$ televoting and $50 \%$ the votes of a professional jury was determinant for the results. According to TRT, professional juries of other countries were acting politically and giving the low points to Turkey. Since its demand to change the voting system was rejected, it decided to withdraw from the contest (Türkiye Eurovision'a neden katılmadı?, 2013). ${ }^{16}$

\footnotetext{
${ }^{15}$ At this point, it is better to remind that the rule for lyrics which was valid from the first contest to the one in 1968 (including 1968) was asking the songs to be in the national language or one of the national languages of the country. EBU let the countries to use some words from different languages in 1969 and in 1973 restrictions on language were abolished. From 1978 to 1999 (including 1999) songs taking part in the contest were again in the national language of the country (Jordan, 2011: 45).

${ }^{16}$ In 2012, the biggest gap of points between two voting systems was on Turkey's. According to the votes coming from professional jury, Turkey earned only 50 points and got the 22nd place. On the basis of televoting, Turkey
} 
In this way, Turkey excluded itself from Europe as a reaction to its belief of exclusion by the professional jury. It decided to turn its back to the contest which has been offering an important opportunity for cultural interaction and communication with Europe in any case.

ESC was a window opening to Europe at a cultural level from 1975 to 2012. On the other hand, it was an organisation where feelings of sadness, anger, excitement, happiness, exclusion were exposed and concepts of religion and nation/nationalism were expressed. This affected the perspective of Turkey on Europe negatively as related to the concepts of identity and nationalism.

\section{Conclusion}

ESC was organised to influence socialist Eastern European countries culturally by the capitalist Western ones. In other words, it can be argued that it was an instrument of the West in the Cold War. Since it was followed in a way, a similar one (Intervision/Sopot) was initiated in Eastern Europe and Eastern bloc was dissolved at the end of the day, ESC seems to achieve its goal. This judgement would naturally bring the question if capitalism-socialism confrontation of the Cold War could be found in the contest. It can be answered that ESC prefered to stay as a cultural instrument. It did not have a political function against the Eastern bloc. This was one of the reasons for the interest of Eastern bloc in the contest. It became a matter of politics in particular of intra/inter state political problems in the capitalist bloc. Moreover reflections of the Arap-Israel conflict as an international problem from past to present sometimes occupied the agenda of ESC. Former socialist countries of the Eastern bloc leaving socialism for capitalism after the end of the Cold War and the ones who declared their independence following the dissolution of USSR began to participate in the contest. Taking part in ESC was considered as a complementary element and a requirement, so to say, of the new regime. They become truly "European" and wanted to indicate their normalisation. ESC was utilized as a platform to introduce their independence and national identity.

Turkey has been a Western-oriented country taking the West as a model of economic and political system and stood by the side of Western Europe during (and after) Cold War. It was aiming to strengthen its ties with Europe and contented for its participation in this cultural organisation, following European music culture and being a part of that culture thanks to the songs that it was represented by. However, the contest made Turkey feel that it had a different national identity compared to Europe. It was disappointed and resentful especially for its low rankings in the period until 2000s. Turkey always considered this issue as "national matter" from the perspective of national identity/religion-nationalism although it was less in degree in 2000s. It was supposed that having a different religion, culture and national identity compared to Europe in addition to its domestic and foreign policy problems would be a disadvantage in the contest.

Turkey was cooperating with Europe at the level of politics but it was being excluded culturally. It was a matter of "they (Europe) do not want us (Turkey)". Naturally, this was not serving for ESC's aim to form a common European culture. However, this confirmed judgement was forgotten temporarily when good results were obtained. It was considered that politicians in Turkey and the "positive image created by them" contributed to the success as much as the song did. Turkey was aware of the political context of ESC and followed a political perspective. For example, political relations with Greece and Cyprus were reflected in the contest periodically. Azerbaijan was always supported by 12 points while points given to Armenia led to political debates.

gained 176 points and was in the 4th place which led to the overall result of 7th in the ranking (Doğru, 2013: 199200). 
The will and interest of Turkey to attend ESC did not emerge together with its demand for being a member of the European Community/Union. However, the enthusiasm to be a part of the community as a state policy in the 1980s and 1990s moved in parallel with its eagerness to take part in the contest. In the 2000s the relations of Turkey with the European Union gained an important acceleration compared to previous years. Full membership negotiations began. In the same period, the interest of Turkey in ESC continued at the state level, it also increased considerably (especially compared to the 1990s) at the societal level. Turkey obtained good results. Its withdrawal from the contest coincided with the time when its relations with European Union was not moving on and the negotiations slowed down.

\section{References}

Begley, C. (2013, September 25). UK humiliated in Eurovision 'post-Iraq backlash'.

Independent. accessed on 04.02.2021

https://www.independent.co.uk/news/media/uk-humiliated-in-eurovision-post-iraq-backlash106132.html

Bekcan, U. (2012, May 23). Bir Soğuk Savaş Ürünü Olarak Eurovision Şarkı

Yarışması. Birikim.com. accessed on 04.02.2021

https://birikimdergisi.com/guncel/406/bir-soguk-savas-urunu-olarak-eurovision-sarkiyarismasi\#.XkUgkXszaUk

Doğru, B. (2013). Coğrafi komşuluğun ve kültürel yakınlığın oy verme davranışına etkisi: Eurovision Şarkı Yarışması. Doğuş Üniversitesi Dergisi, 14(2), 195-212.

Eurovision'a Doğru 12. Bölüm, (2012, May 25). Youtube.com. accessed on 04.02.2021 https://www.youtube.com/watch?v=LufDmdD3RSI

Goldenberg, S. (2000, May 12). Outraged Israel disowns daring Eurovision entry.

Theguardian.com accessed on 04.02.2021

https://www.theguardian.com/world/2000/may/12/israel

Harris, C. (2019, May 17). How politics is the perennial elephant in the room at

Eurovision. Euronews.com. accessed on 04.02.2021

https://www.euronews.com/2019/05/17/how-politics-is-the-elephant-in-the-room-at-eurovision

Hintermayr, M. M. (2016, May 15). Eurovision Cold War. Geopolitics and Queerness

at the Eurovision Song Contest in 2007. Fernetzt blog. accessed on 04.02.2021 https://www.univie.ac.at/fernetzt/eurovision-cold-war-geopolitics-and-queerness-at-the-eurovisionsong-contest-in-2007/ 
Iceland fined for Eurovision pro-Palestinian protest. (2019, September 21). france24.com. accessed on 04.02.2021

https://www.france24.com/en/20190921-iceland-fined-for-eurovision-pro-palestinian-protest İzlanda ve İrlanda'dan Eurovision için İsrail'i boykot çağrısı. (2018, May 17).

NTV.com. Accessed on 04.02.2021

https://www.ntv.com.tr/sanat/izlanda-ve-irlandadan-eurovision-icin-israili-boykotcagrisi,ugFaSdwUP0eo2OOgOflgtg

Jordan, P. (2010, November 18). The truth about politics at the Eurovision Song Contest. ESCInsight.com. accessed on 04.02.2021

https://escinsight.com/2010/11/18/the-truth-about-the-politics-of-eurovision/

Jordan, P. (2011). The Eurovision Song Contest: Nation branding and nation building

in Estonia and Ukraine. Unpublished PhD thesis. Glasgow: University of Glasgow, Central \& East European Studies.

Kuyucu, M. (2011). Türkiye'nin Eurovision Serüveni. İstanbul: Esen Kitap.

Levy, G. (2009, May 16). Top 10 Eurovision controversies. Time.com.

accessed on 04.02.2021

http://content.time.com/time/specials/packages/completelist/0,29569,1896688,00.html

Oliver, S. (Director). (2011). The secret history of Eurovision [Documentary].

Australia: BBC Worldwide.

Riegert, B. (2019, Mayıs 18). Yorum: Eurovision şarkı yarışması eğlence mi siyaset mi?

dw.com. accessed 04.02.2021

https://www.dw.com/tr/yorum-eurovision-şarkı-yarışması-eğlence-mi-siyaset-mi/a-48785611

Rosenberg, S. (2012, May 13). The Cold War rival to Eurovision. BBC News.

accessed on 04.02.2021 https://www.bbc.com/news/magazine-18006446

Rules. (2021, January 9). Eurovision.tv. accessed on 09.01.2021 https://eurovision.tv/about/rules/

Sander, O. (2003). Siyasi tarih, ilkçağlardan 1918'e. Ankara: İmge Yayınları.

Saunders, F. S. (2000). Who paid the piper? The CIA and cultural Cold War. Londra:Granta Books

Serbia-Montenegro in pop song row. (2006, March 14). BBCnews. accessed on 04.02.2021 http://news.bbc.co.uk/2/hi/europe/4805014.stm

Tellal, E. (2013). Savaş sonrası dünya düzeni (1945-1950). in i. Ortaylı (ed.), Siyasi tarih II (pp. 64-89). Eskişehir: Anadolu Üniversitesi Yayınları.

The first ever contest. (2021, January 10). Eurovision.tv. accessed on 10.01.2021 
https://eurovision.tv/event/lugano-1956

The Hague 1980. (2021, January 10). Eurovision.tv. accessed on 10.01.2021

https://eurovision.tv/event/the-hague-1980/final/results/turkey

Türkiye Eurovision'a neden katılmadı? (2013, September 17). TRThaber.com. accessed on 04.02.2021 https://www.trthaber.com/haber/medya/turkiye-eurovisiona-neden-katilmadi101153.html

Türkiye'nin ESC tarihi 6/4. (2012, May 21). Youtube.com. accessed on 04.02.2021

https://www.youtube.com/watch?v=m1EmOIIADdk

United States Congress. (1978). The CIA and the media. Washington: U.S. Government

Printing Office.

Vuletic, D. (2017, November 6). The Intervision song contest. Fiatifta.org. accessed on 04.02.2021 http://fiatifta.org/wp-content/uploads/2017/11/The-Intervision-Song-Contest-Dean-Vuletic.pdf

Watson, J., \& Slee, A. (2019, May 16). Eurovision was meant to be apolitical. It's

been anything but. ABC News. accessed on 04.02.20211 https://www.abc.net.au/news/2019-0516/eurovision-political-and-diplomatic-history-of-song-contest/11109018

Wellings, B., \& Kalman, J. (2019). Entangled histories: Identity, Eurovision and

European integration. in B. Wellings, J. Kalman, \& K. Jacotine (eds.), Eurovisions: Identity and the international politics of the Eurovision Song Contest since 1956 (pp. 1-20). Singapore: Palgrave Macmillan.

Wolther, I. (2012). More than just music: The seven dimensions of the Eurovision song contest. Popular Music, 31(1), 165-171. 